\title{
Effectiveness of Star Fruit Leaf Extract on the Growth of Streptococcus Sanguinis: An In Vitro Study
}

\author{
Minasari Nasution ${ }^{1}$, Yolanda Simatupang ${ }^{2}$, Dennis Dennis ${ }^{3}$
}

\begin{abstract}
Aim: The study was aimed to examine the effectiveness level of minimum inhibition concentration (MIC) and minimum bactericidal concentration (MBC) of the star fruit leaf extract on the growth of Streptococcus sanguinis (S. sanguinis) bacteria at concentration 60, 40, 20, 10, and 5\%.

Materials and methods: This study was laboratory experimental research with the posttest-only control group design. The effectiveness test of the star fruit leaf extract on the growth of S. sanguinis was performed with dilution method. The leaf extract of star fruit was made by the maceration technique from each concentration, suspension of $S$. sanguinis bacteria was added, repetition done four times, and then observation was conducted. The data analysis used was the one-way ANOVA test.

Results: The result showed that MIC concentration of the extract on the growth of S. sanguinis was $5 \%$ and MBC concentration was $10 \%$.

Conclusion: The star fruit leaf extract has antimicrobial efficacy against S. sanguinis.

Clinical significance: The star fruit leaf extract has the potential capacity to prevent and cure dental caries, recurrent aphthous stomatitis (RAS), and periodontal disease.

Keywords: Minimum bactericidal concentration, Minimum inhibition concentration, Star fruit leaf extract, Streptococcus sanguinis.

World Journal of Dentistry (2020): 10.5005/jp-journals-10015-1731
\end{abstract}

\section{INTRODUCTION}

Public interest in traditional medicine is quite high (Ministry of Health Republic of Indonesia (MOH RI. 2009) as much as $34.41 \%$. According to statistical data from the WHO, $60 \%$ of world's population uses traditional medicine while $40 \%$ uses modern medicine. Indonesia is the second country in the world that has the diversity of plants to improve health. In this world, there are 30,000 species of herbs used as medicine. A total of 940 species are successful as medicine, but currently only 283 species have been utilized.

Star fruit (Averrhoa bilimbi L.) is one of the plants that has not been specifically cultivated but often used as a traditional medicine. This plant is used to overcome various diseases such as cancer sores, dental pain, bleeding gums, cough, diabetes, rheumatism, mumps, acne, diarrhea, high blood pressure, and stroke. The part of the plant that Liantari studied was the leaf, containing tannins, flavonoids, saponins, and triterpenoids, which showed that the star fruit plant has an antibacterial activity. ${ }^{2}$

Tannin as an antimicrobial compound through its several mechanisms inhibits microbial enzymes and bacterial growth by reacting with cell membranes and inactivating microbial essential enzymes and genetic material. ${ }^{2,3}$ Flavonoid active compounds have the ability to form complex compounds with bacterial proteins through hydrogen bonds, causing cell wall structures and bacterial cytoplasmic membranes that contain proteins to become unstable and lose their biological activity. Furthermore, the bacterial cells will be disrupted by the increased permeability of bacterial cells itself and will cause bacterial lysis and eventually shows no bacterial growth occurs. Triterpenoid can damage the lipid fraction of the cytoplasmic membrane, thus disrupting the functioning of the membrane or cell wall formation. ${ }^{3}$ The previous study done by Sari showed that the young star fruit leaf contains $1.60 \%$ of tannin and the old star fruit leaf contains $1.8 \%$ of tannin. ${ }^{4}$ The study done by
1,2Department of Oral Biology, Faculty of Dentistry, Universitas Sumatera Utara, Medan, Sumatera Utara, Indonesia

${ }^{3}$ Department of Conservative Dentistry, Faculty of Dentistry, Universitas Sumatera Utara, Medan, Sumatera Utara, Indonesia

Corresponding Author: Minasari Nasution, Department of Oral Biology, Faculty of Dentistry, Universitas Sumatera Utara, Medan, Sumatera Utara, Indonesia, Phone: +628126097057, e-mail: minasari_ nasution@yahoo.co.id

How to cite this article: Nasution $M$, Simatupang $Y$, Dennis $D$. Effectiveness of Star Fruit Leaf Extract on the Growth of Streptococcus Sanguinis: An In Vitro Study. World J Dent 2020;11(3):196-200.

Source of support: Nil

Conflict of interest: None

Sriherfyna et al. on the star fruit leaf shows that it has antibacterial activity against Staphylococcus aureus and Escherichia coli. ${ }^{3}$

The active substance of the star fruit leaf that has antimicrobial effect quickly reacts with the cell membrane and inactivates the essential enzymes or genetic material. ${ }^{2,5}$ This condition causes tension in the cell wall and cytoplasmic membrane and an increase in permeability of the cell wall so that the cell is destroyed and bacterial growth does not occur. ${ }^{2-5}$

\section{Classification of Star Fruit}

Star fruit (Averrhoa bilimbi L.) belongs to the species of the Averrhoa family. ${ }^{2,4}$ Taxonomically, star fruit can be classified as follows: ${ }^{5}$

Kingdom: Plantae (plants)

Subkingdom: Tracheobionta (vicious)

Super division: Spermatophyta (produce seeds)

Division: Magnoliophyta (flowering)

Class: Magnoliopsida (dicoted)

Subclass: Rasidae

Ordo: Geraniales 
Family: Oxalidaceae (Star fruit)

Genus: Averrhoa

Species: Averrhoa bilimbi L.

\section{Star Fruit Morphology}

Star fruit can grow at an altitude of 5-500 $\mathrm{m}$ above sea level. The height reaches 5-10 $\mathrm{m}$ with a short main stem. Branching a little, the location of low branches, bumpy and stem diameter about 30 $\mathrm{cm}$ direction leaning upward, young branches with smooth hairlike velvety brown. Flowers are in the form of jasmine in groups, out of a large trunk or branch. They are star-shaped and reddish purple in color. Star fruit has ellipse shape like torpedo with length of $4-10 \mathrm{~cm}^{2,4}$

Young fruit is green with the rest of the petals stuck to the end. The ripe fruit is yellow or pale yellow, and the flesh is watery and very sour. The fruit has sour taste, shiny and thin rind, which is often used as a spice for cooking and as mixture of herb. Seeds are oval-shaped measuring $6 \mathrm{~mm}$, shaped flat, and brown, and covered with mucus. This tree grows in places exposed to direct sunlight and quite moist. Almost all parts of the star fruit can be utilized; one of them is the leaf. ${ }^{2,4}$

Leaf of star fruit has odd pinnate with 21 to 45 pairs of split or half-pairs and oval-shaped leaves. Star fruit plant has shortstemmed leaves, rounded oval, pointed, rounded base, flat edge, $2-10 \mathrm{~cm}$ long, and $1-3 \mathrm{~cm}$ in width. The leaf thickness is paper-thin. The upper surface of the leaf is dark green and there is fine hair and the lower surface has lighter color $^{4-6}$ (Fig. 1).

\section{Streptococcus sanguinis}

S. sanguinis is a gram-positive bacterium in the form of coccus (round) with diameter 0.6-1.0 $\mu \mathrm{m}$ arranged like a chain (Fig. 2). S. sanguinis is nonmotile, negative catalase, grows optimum at $37^{\circ} \mathrm{C}$ with $\mathrm{pH} 7.4-7.6$, opaque colored, and the surface is rough (only $7 \%$ is mucoid). S. sanguinis is a type of alpha-type S. hemoliticus bacteria called a nonhemolytic strain that can normally be found in the oral cavity. The observation under the microscope is round and arranged like chains. Based on the science of taxonomy, S. sanguinis bacteria is classified as follows: ${ }^{8}$

Kingdom: Bacteria

Filum: Firmicutes

Class: Bacilli

Ordo: Lactobacilalles

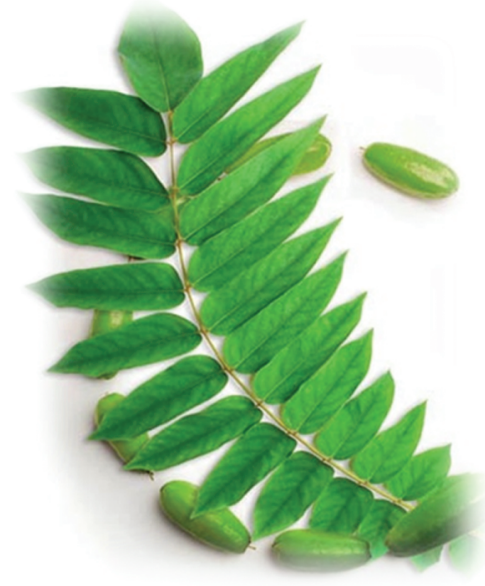

Fig. 1: Star fruit leaf (personal documentation)
Family: Streptococcaceae

Genus: Streptococcus

Species: Streptococcus sanguinis

Based on the need for oxygen, S. sanguinis is classified as facultative anaerobic bacteria, i.e., when it comes contact with oxygen it can still continue its growth. However, when oxygen is less available then metabolism occurs; the bacteria can ferment with the aid of synthesis of adenosine triphosphate (ATP). ${ }^{9,10}$ These bacteria colonize on the tooth surface and mucous membranes of the oral cavity, thus forming biofilm. ${ }^{9}$

\section{Materials and Methods}

This type of research was done in experimental laboratory with the posttest-only control group design. The research sample was S. sanguinis, which had been identified and cultured at the clinical microbiology unit of Universitas Sumatera Utara (USU) hospital. This study used samples of $S$. sanguinis bacteria with predetermined inclusion. The inclusion criteria were the bacteria cultured at the clinical microbiology unit, which had been isolated previously from periodontal disease. The measurement or observation was performed after treatment. The star fruit leaf extraction process was done at the laboratory of Traditional Medicines of Faculty of Pharmacy, Universitas Sumatera Utara (USU). Identification, breeding, and testing of samples were conducted at the clinical microbiology unit of USU hospital.

Sample size of this experimental research was determined using Federer's formula, i.e.

$$
(T-1)(R-1) \geq 15
$$

where $t=$ amount of treatment and $r=$ number of replication

This research uses seven treatment groups:

- Group I: star fruit leaf extract $60 \%$

- Group II: star fruit leaf extract $40 \%$

- Group III: star fruit leaf extract $20 \%$

- Group IV: star fruit leaf extract $10 \%$

- Group V: star fruit leaf extract 5\%

- Group VI: chlorhexidine

- Group VII: aqua bidest

Thus, the treatment amount $(t)=7$, then

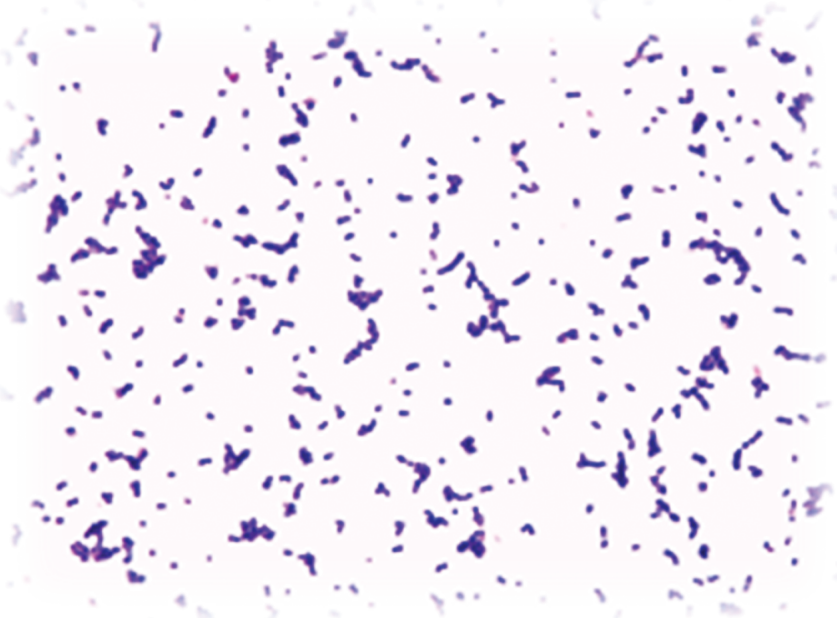

Fig. 2: Gram staining shows characteristics of S. sanguinis ${ }^{7}$ 


$$
\begin{aligned}
(T-1)(R-1) & \geq 15 \\
(7-1)(R-1) & \geq 15 \\
R-1 & \geq 2.5 \\
R & \geq 3.5 \\
R & \geq 4
\end{aligned}
$$

The required number of samples is one with replication four times, which meant that in the group I-VII four repetitions in each group were done to prevent the occurrence of bias.

\section{Star Fruit Leaf Extract Preparation}

Star fruit leaves $1.5 \mathrm{~kg}$ were cleaned by washing under tap water and then dried with air spray. Dried star fruit leaves were pollinated using a blender device and then stored in a sealed container (Fig. 3).

\section{Extraction Process of Powder Star Fruit Leaf}

The leaves of star fruit were mixed with ethanol. Stir was performed for \pm 15 minutes for 5 days. The maceration bottle was attached and connected to the faucet appropriately. Then, cotton was put at the end of the bottle and solidified. The filter paper was placed above of the cotton so that it coated the bottom of the bottle. Then the powder was mixed with ethanol in the filter tube, holding the liquid extract in one container. The water machine and faucet were turned on so that water would go into the rotavapor. The product of maceration was put into a flask and the flask was put in place. The heater was turned on; the temperature was adjusted by pressing the set button and up and down button. The handle position was opened to unlock and the flask was lowered until approximately half of the flask size was submerged into the heated liquid. The handle position was returned to the locked position. The vacuum was turned on and the vacuum faucet was turned off. The maceration was refilled when it was reduced. The container flask was removed if it was full of ethanol. After the maceration became thick as melted chocolate, the rotavaporation process was stopped and transferred to a container. The thick extract was diluted with ethanol to obtain the extract of star fruit leaves with concentrations at $60,40,20,10$, and $5 \%$.

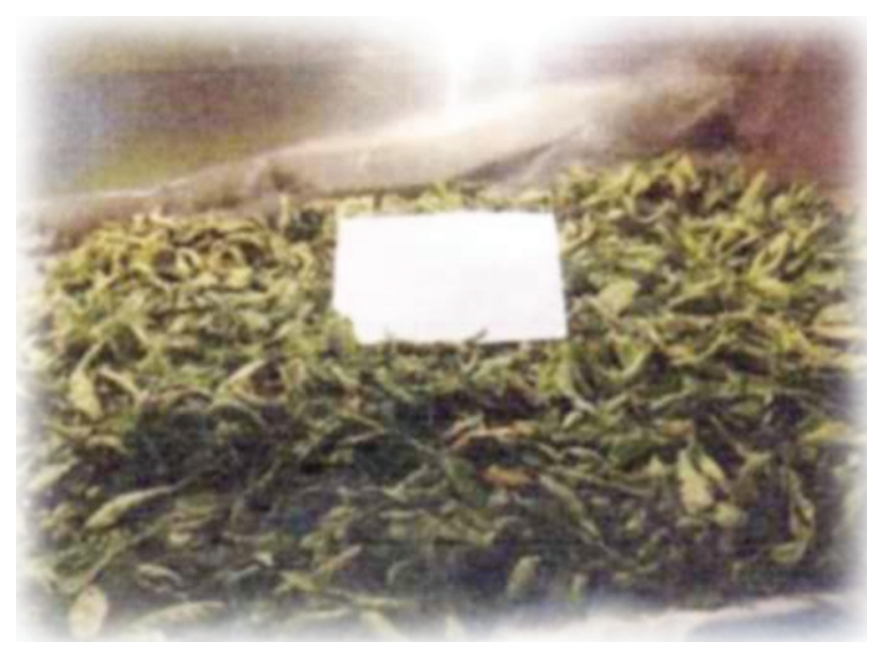

Fig. 3: Dried star fruit leaves (personal documentation)

\section{Results}

The MIC concentration was obtained from observing the cloudy tube subculture results in the TYC petri dish (tryptone, yeast extract, cysteine). TYC petri dishes with the lowest concentrations can inhibit the growth of bacterial colonies showing MIC concentrations. The growth of S. sanguinis bacteria is characterized by the presence of spherical colonies, shiny, smooth, arranged in irregular, white, or cloudy groups.

Table 1 shows that a 5\% MIC concentration in which there is still a growth of bacterial colonies. The MBC concentration is obtained from observing the cloudy tube subculture result in TYC petri dish. TYC petri dishes with the lowest concentrations of bacterial colony growth showed no concentrations of MBC. Concentrations of $60,40,20$, and $10 \%$ have no bacterial colony growth. The lowest concentration was found in the concentration of $10 \%$ of the star fruit leaf extract that showed the concentration of MBC.

Only star fruit extract $5 \%$ showed bacteria colony. Meanwhile, the star fruit extract at concentration 60,40, 20, and 10\% showed no bacteria at all (Table 2). The one-way ANOVA test was used to test the difference of bacterial colonies in some concentrations of the star fruit leaf extract, chlorhexidine, and aqua bidest. It showed that there were significant differences in each concentration. The significant difference was in the concentration of $5 \%$ with $p$ value $=0.000$ (Table 2). Data at a concentration of $5 \%$ were found to be normally distributed using the Shapiro-Wilk test.

After the one-way ANOVA test, the post hoc test was done as a follow-up test to see the difference of bacterial colony at various concentrations. The results of the post hoc test showed that the concentrations of $60,40,20$, and $10 \%$ and chlorhexidine had a significant difference with $5 \%$ concentration and aqua bidest (negative control). With each $p$ value $=0.004$ and $p=0.000$ (Table 3).

\section{Discussion}

S. sanguinis was chosen because it functions as attachments to other microorganisms that colonize the tooth surface, form dental plaque, contribute to the development of caries, recurrent aphthous stomatitis (RAS), and periodontal disease. ${ }^{6,7}$ S. sanguinis has $100 \%$ incidence range found in the oral cavity. ${ }^{11,12}$

The study was conducted in vitro by the dilution method using ethanol at each concentration of the star fruit leaf extract. Each extract concentration was dropped on the Mueller Hinton Broth (MHB) medium and S. sanguinis suspension then incubated in an incubator for 24 hours at $37^{\circ} \mathrm{C}$. After observing, it turns out that all tubes at each turbid concentration are influenced by concentrated extracts. To prove that the tubes contained bacterial growth, culture was carried out on TYC media to obtain MIC and MBC.

After 24 hours, the subculture results were then observed to obtain the MIC and MBC concentrations. Subcultures with fewer colonies are subcultures showing a bacteriostatic effect, and the minimum concentration of colony growth in a smaller number of all repetitions at each concentration is referred to as the MIC concentration. Subcultures that did not have colony growth showed bactericidal effects, and the smallest concentration of colonies without growth was the concentration of MBC. This research was repeated four times and the average concentration of MIC and MBC from the star fruit leaf extract was calculated.

In this study, researchers compared the effectiveness of the star fruit leaf extract on the growth and the number of colonies 
Table 1: The best result of MIC and MBC concentration of star fruit leaf extract on S. sanguinis in TYC media

\begin{tabular}{llllll}
\hline Tube & Test material & Repetition 1 & Repetition 2 & Repetition 3 & Repetition 4 \\
\hline 1 & Star fruit leaf extract 60\% & - & - & - & - \\
2 & Star fruit leaf extract 40\% & - & - & - & - \\
3 & Star fruit leaf extract 20\% & - & - & - & - \\
4 & Star fruit leaf extract 10\% & - & - & + & + \\
5 & Star fruit leaf extract 5\% & + & + & - & - \\
6 & Chlorhexidine 0.1\% & - & - & + & + \\
7 & Aqua bidest & + & + & & + \\
\hline
\end{tabular}

Note: $(+)=$ colony growth $(-)=$ no colony growth

Table 2: Different test results amount of bacterial colonies from some concentration of star fruit leaf extract against S. sanguinis in TYC media

\begin{tabular}{llcccccc} 
Petri & Test material & Repetition 1 & Repetition 2 & Repetition 3 & Repetition 4 & $\bar{X} \pm$ SD & $0.000^{*}$ \\
\hline 1 & Star fruit leaf extract 60\% & 0 & 0 & 0 & 0 & $0 \pm 0.000$ \\
2 & Star fruit leaf extract 40\% & 0 & 0 & 0 & 0 & $0 \pm 0.000$ \\
3 & Star fruit leaf extract 20\% & 0 & 0 & 0 & 0 & $0 \pm 0.000$ \\
4 & Star fruit leaf extract 10\% & 0 & 0 & 0 & 0 & $0 \pm 0.000$ \\
5 & Star fruit leaf extract 5\% & 21 & 17 & 24 & 22 & $21 \pm 2.944$ \\
6 & Chlorhexidine 0.1\% & 0 & 0 & 0 & 0 & 0.000 \\
7 & Aqua bidest & 325 & 354 & 385 & 356 & $355 \pm 24.509$ \\
\hline
\end{tabular}

One-way ANOVA test, ${ }^{*}$ Significant $p<0.05$

Table 3: Different test results showing the colony amount of S. sanguinis at various concentrations of star fruit leaf extract in TYC media

\begin{tabular}{|c|c|c|c|c|c|c|c|}
\hline \multirow{2}{*}{$\begin{array}{l}\text { Tested } \\
\text { concentration }\end{array}$} & \multicolumn{7}{|c|}{ The value of $p$ against the comparison concentration } \\
\hline & $60 \%$ & $40 \%$ & $20 \%$ & $10 \%$ & $5 \%$ & Chlorhexidine & Aqua bidest \\
\hline $\begin{array}{l}\text { Star fruit leaf } \\
\text { extract } 60 \%\end{array}$ & - & 1 & 1 & 1 & $0.004^{*}$ & 1 & $0.000^{*}$ \\
\hline $\begin{array}{l}\text { Star fruit leaf } \\
\text { extract } 40 \%\end{array}$ & 1 & - & 1 & 1 & $0.004^{*}$ & 1 & $0.000^{*}$ \\
\hline $\begin{array}{l}\text { Star fruit leaf } \\
\text { extract } 20 \%\end{array}$ & 1 & 1 & - & 1 & $0.004^{*}$ & 1 & $0.000^{*}$ \\
\hline $\begin{array}{l}\text { Star fruit leaf } \\
\text { extract } 10 \%\end{array}$ & 1 & 1 & 1 & - & $0.004^{*}$ & 1 & $0.000^{*}$ \\
\hline $\begin{array}{l}\text { Star fruit leaf } \\
\text { extract 5\% }\end{array}$ & $0.004^{*}$ & $0.004^{*}$ & $0.004^{*}$ & $0.004^{*}$ & - & $0.004^{*}$ & $0.000^{*}$ \\
\hline $\begin{array}{l}\text { Chlorhexidine } \\
0.1 \%\end{array}$ & 1 & 1 & 1 & 1 & $0.004^{*}$ & - & $0.000^{*}$ \\
\hline Aquabidest & $0.000^{*}$ & $0.000^{*}$ & $0.000^{*}$ & $0.000^{*}$ & $0.000^{*}$ & $0.000^{*}$ & - \\
\hline
\end{tabular}

Post hoc test, *Significant $p<0.05$

between S. sanguinis. The unpaired $t$-test results obtained showed a significant difference with the value of $p=0.000(p<0.05)$ at concentrations of 10 and $5 \%$ of the star fruit leaf extract against the growth of S. sanguinis.

The previous study done by Taliningrum et al. proved that the extract of star fruit leaves with ethanol solvent has antimicrobial activity against $S$. sanguinis. ${ }^{13}$ The star fruit leaf extract was made with the maceration technique at concentration of 2.5, 5, 10, 20, and $40 \%$. Testing of antibacterial activity was performed using the diffusion method. The mean clear zone formed at the edge of the wells from each concentration was 13.7767, 15.2667, 16.0000, 16.9000 , and 16.9000. Hence, this study showed that the star fruit extract has potent antimicrobial activity against S. sanguinis ${ }^{13}$
Factors that affect the ability of the star fruit leaf extract to play an active role as an antibacterial are flavonoids, tannins, saponins, and triterpenoids. ${ }^{14}$ The mechanism of action of flavonoids as antibacterial is to form complex compounds with extracellular and dissolved proteins so that they can damage the bacterial cell membrane and followed by the release of intracellular compounds, in addition it plays a role in the inhibition of DNA-RNA synthesis by hydrogen bonding with a buildup of nucleic acid bases; flavonoids also play a role in inhibiting energy metabolism. ${ }^{15}$ This compound will disrupt energy metabolism by inhibiting the respiratory system, because it requires sufficient energy for the active absorption of various metabolites and for macromolecular biosynthesis. $^{14,15}$ 
Tannin compounds have antibacterial activity, which can damage bacterial cell membranes because tannins are able to form complex bonds with proteins that inactivate bacterial adhesin. ${ }^{14,15}$ Inactivation of bacterial adhesin enzymes and protein coagulators inhibited bacteria. It causes protoplasmic coagulation so that there is contraction of the bacterial cell wall resulting in increased permeability of the bacterial wall. ${ }^{14,15}$ Increased permeability of bacterial cell wall membranes is followed by intracellular leakage, which causes cell components to exit so that physiological activity of bacterial cells decreases and causes bacterial growth to not occur/lysis and even bacterial death. . $^{4,15}$

Saponin compounds act as antibacterials, which can reduce the surface tension of cell wall membranes resulting in increased bacterial permeability resulting in cell leakage and intracellular outflow; these compounds diffuse through the outer membrane and cell walls that are vulnerable, and then bind the cytoplasmic membrane and disrupt and reduce stability. This causes the cytoplasm to leak out of the cell resulting in cell death. ${ }^{14-16}$

Triterpenoid compounds are also known to be active as antibacterial. The antibacterial role of triterpenoids can break down lipophilic membranes. In addition, phenolic compounds and terpenoids have a main target, namely the cytoplasmic membrane that refers to its hydrophobic nature. ${ }^{14-16}$

The result of this study was supported by other study on the effectiveness of the antibacterial power of wuluh starfruit leaf powder (A. bilimbi L.) on the growth of Streptococcus sp. using the weight of wuluh starfruit leaf powder (A. bilimbi L.) $0.05 \mathrm{~g}, 0.1$ $\mathrm{g}, 0.15 \mathrm{~g}$, and $0.2 \mathrm{~g}$. The antibacterial activity test was carried out to determine the amount of the inhibition zone around the well. It showed that star fruit leaf powder (A. bilimbi L.) can inhibit the growth of Streptococcus sp. ${ }^{2}$

This study was in accordance with the study done by Kumar et al. using the chloroform extract of star fruit ( $A$. bilimbi L.) leaf, which showed the inhibitory effect of the star fruit leaf extract against oral gram-positive microorganisms. ${ }^{17}$

This study was in line with study done by Zheng et al. that showed extract of star fruit leaves with concentrations of 2.5, 5, 10,20 , and $40 \%$ had an effect on the inhibition zone of S. sanguinis growth. The clear zone was formed on the edge of the well, which proves the antibacterial power generated by the star fruit leaf extract (A. bilimbi L.) in inhibiting the growth of $S$. sanguinis bacteria. $^{6}$

\section{CONCLUSION}

From the results of the study, the effectiveness of concentrations of the star fruit leaf extract on S. sanguinis growth shows that MIC is $5 \%$ and $M B C$ is $10 \%$. Star fruit (A. bilimbi L.) leaf has potential inhibitory effect on the growth of $S$. sanguinis; thus, it can be used for prevention and cure of dental caries, RAS, and periodontal disease.

\section{References}

1. Republic of Indonesia ministry of health's health research and development agency. Basic Health Research (RISKESDAS). Jakarta 2013. pp. 118-119.

2. Liantari DS. Effect of star fruit leaf extract for streptococcus mutans growth. J Majority 2014;3(7):27-33.

3. Sriherfyna FH, Zubaidah. Physical-chemical characteristics and antibacterial activity of star fruit leaf extract (Averrhoa bilimbi L.). J Food Agroind 2016;4(1):400-409.

4. Sari M, Suryani C, Effect of star fruit extract (Averrhoa bilimbi L) in inhibiting the growth of the fungus Candida albicans in vitro In: Department of Faculty of Mathematics and Natural Sciences Universitas Negeri Medan. Conference proceedings of National Seminar in Biology and learning, 2014: pp. 325-32.

5. Yulianingtyas A, Kusmartono B. Optimization of solvent volume and maceration time of star fruit leaf extract (Averrhoa bilimbi L). J Chem Sci 2016;10(2):58-64.

6. Zheng W, Tan TK, Paterson IC, et al. Streptobase an oral streptococcus mitis group genomic resource and analysis platform. PLoS. ONE. 2016;11(5):1-19. DOI: 10.1371/journal.pone.0151908.

7. Suwandi T. Development of antibacterial potential of hibiscus sabdariffa L. (Rosela) petals against Streptococcus sanguinis inducing gingivitis towards standardized herbal medicines. Dissertation. Jakarta: Universitas Indonesia; 2012. pp. 19-22.

8. Ge X, Kitten T, Chen Z, et al. Identification of Streptococcus sanguinis genes required for biofilm formation and examination of their role in endocarditis virulence. Infect Immun 2008;76(6):2551-2559. DOI: 10.1128/IAI.00338-08.

9. Anggraini N, Saputra O. Efficacy of star fruit (Averrhoa bilimbi L.) on the healing of acne vulgaris. J Majority 2016;5(1):76-80.

10. Brooks GF, Butel JS, Ornston LN, et al. Medical microbiology. Translation by Maulany NRF Jakarta: Medical Book Publisher; 1996. p. 219.

11. Philip K, Teoh WY, Muniandy S, et al. Pathogenic bacteria predominate in oral cavity of Malaysian subjects. J Biolog Sci 2009;9(5):438-444. DOI: 10.3923/jbs.2009.438.444.

12. Nurdiana JusriM. Management of major recurrent aphthous stomatitis with secondary infections. J Dentofas 2011;10(1):44-46.

13. Taliningrum KK, Kholifa M, Rochmanita $N$. The difference in the various concentrations of $70 \%$ ethanol extract of star fruit leaf (Averrhoa bilimbi L.) as mouthwash to inhibit the growth of sStreptococcus anguis bacteria. Universit Muhammad Surak 2015. 2-11.

14. Morita C, Sumioka R, Nakata M, et al. Cell wall-anchored nuclease of Streptococcus sanguinis contributes to escape from neutrophil extracellular trap-mediated bactericidal activity. J P One 2014;9(8):110. DOI: 10.1371/journal.pone.0103125.

15. Marsh PD, Martin MV, Lewis MAD, et al. Oral microbiology. 5th ed., China: Churchill Livingstone ELSEVIER; 2009. p. 33.

16. Alhassan AM, Ahmed QU. Averrhoa bilimbi linn.: a review of its ethnomedicinal uses, phytochemistry, and pharmacology. J. Pharm. Bioallied Sci. 2016;8(4):265-271. DOI: 10.4103/0975-7406.199342.

17. Kumar KA, Gousia SK, Anupama. A review on phytochemical constituents and biological assays of Averrhoa bilimbi L. Int J Pharma Pharmaceut Sci Res 2013;3(4):136-139. 